\section{Drugs of Radiological Pharmacology. Reprofiling: Caffeine}

\section{N.N. Kolotilov}

SI «Institute of Nuclear Medicine and Diagnostic Radiology of NAMS of Ukraine», Kyiv, Ukraine
Caffeine $\left(\mathrm{C}_{8} \mathrm{H}_{10} \mathrm{~N}_{4} \mathrm{O}_{2}\right.$, molar mass - $194.19 \mathrm{~g} /$ mol, mateine, theine, guaranine) is a purine alkaloid, colorless or white bitter crystals. It is a psychostimulant found in plants such as coffee, tea, cocoa, Paraguayan holly (mate), guarana, cola and others (figure) $[5,17]$.

The plant-based alkaloids related to caffeine are theobromine and theophylline (constructive knowledge in terms of drug reprofiling). They are chemically methylated xanthines and are structurally related to important metabolic compounds such as purines (adenine, guanine), xanthine and uric acid. In therapeutic doses, theophylline and theobromine have antihypertensive and antispasmodic effects, caffeine hypertensive and antispasmodic effects. These alkaloids are diuretics (figure) [6].

The fatal acute oral dose of caffeine for humans is estimated at $10-14 \mathrm{~g}(150-200 \mathrm{mg} / \mathrm{kg}$ of body weight). Caffeine in doses up to 10 g caused convulsions and vomiting, with full recovery after 6 hours. In humans, severe side effects have been observed with $1 \mathrm{~g}(15 \mathrm{mg} / \mathrm{kg})$ caffeine, including anxiety, nervousness and irritability, tachycardia and rapid breathing, progression to delirium, vomiting, neuromuscular tremors and seizures [5]. There are reports of fatalities even at doses of $57 \mathrm{mg} / \mathrm{kg}$ [6].

The median lethal dose of oral caffeine for albino rats was $192 \pm 18 \mathrm{mg} / \mathrm{kg}$. Clinical signs of poisoning with these doses: schizophrenic withdrawal symptoms, hyperreflexia, dizziness, ataxia, signs of pain, cataleptic postures, cataplexia, diarrhea, anuria, anorexia, adipsia, hypothermia, blepharitis, and weight loss. Death occurred in $30 \pm 9.6$ hours and was immediately caused by respiratory failure after tetanic seizures or cardiovascular collapse. An autopsy showed the presence of fulminant gastroenteritis, pulmonary hyperemia, hepatitis, nephritis, toxic effects on the heart, spleen, pancreas, thymus, adrenal glands and dehydration of many organs and tissues. Survival was characterized by severe polydipsia and polyuria [5].

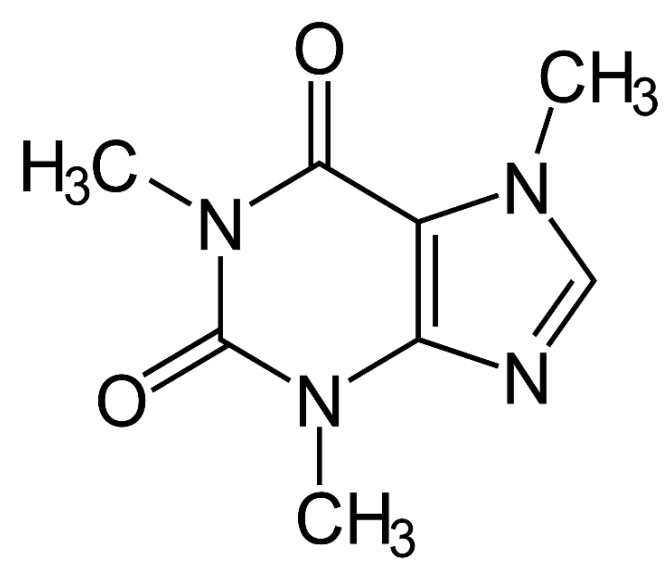

Caffeine

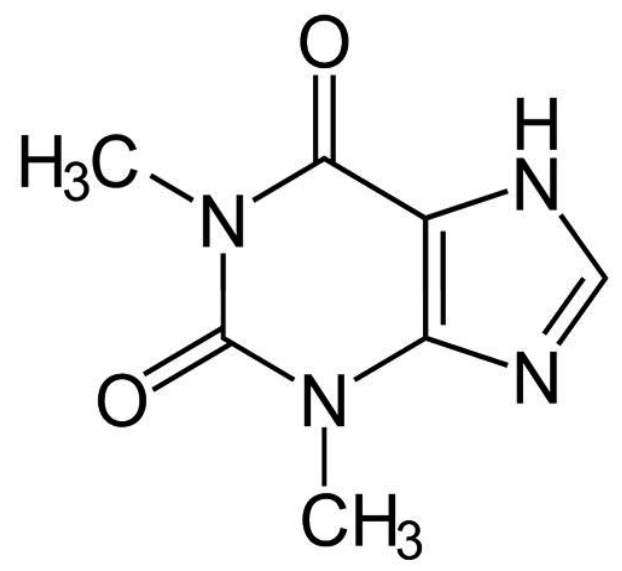

Theophylline

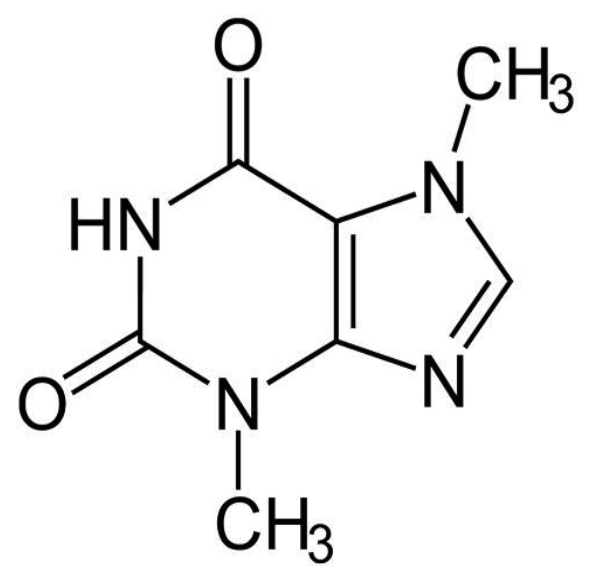

Theobromine 
Caffeine is one of the most common selfadministered (social) drugs. It is in the top five most commonly prescribed treatments in neonatology. The tonic effect of caffeine is based on its influence on the central nervous system (CNS). Due to its lyophilic nature, caffeine (1,3,7-trimethylxanthine) has a $99 \%$ absorption rate and reaches its maximum concentration in blood plasma after 30-60 minutes. It is rapidly distributed throughout the body and penetrates the blood-brain barrier by diffusion and through the absorbing transport system [5, 6, 17].

Caffeine as a drug originally belongs to the group of psychostimulants or analeptics, that is, drugs that, in therapeutic doses, restore and stimulate the functions of the vital centers of the medulla oblongata - respiratory and vasomotor, and also stimulates the cortex and subcortical centers of the brain. The effect of caffeine on the central and peripheral nervous systems is dose dependent. At doses exceeding the therapeutic ones, the stimulating effect turns into a depressing one [17]. The change in blood pressure appears as a result of the double action of caffeine on the vascular system: a direct effect on the smooth muscles of the vessels and through the vasomotor center of the medulla oblongata. At therapeutic doses of caffeine, the cerebral vessels are narrowed, which explains the beneficial effect of this drug at migraines. Caffeine stimulates skeletal muscle contraction through both central (via the CNS) and direct effects $[16,17]$.

Several hypotheses explaining the mechanisms of various effects of caffeine's influence on the body are known: blockade of adenosine receptors (found in all body tissues); inhibition of the phosphodiesterase enzyme; induction of intracellular calcium transport.

In the human body, caffeine acts as a competitive antagonist of adenosine receptors. At a concentration in blood plasma, which is achieved by drinking 1-3 cups of coffee (100 $\mu \mathrm{mol})$, it completely suppresses the adenosine effects, but has no direct impact on the level of cyclic adenosine monophosphate (cAMP, an ATP derivative) or shifts in calcium concentration. To achieve the latter effects, caffeine (over $200 \mu \mathrm{mol})$ toxic levels are needed. Concentrations exceeding $500 \mu \mathrm{mol}$ are lethal. Adenosine and its derivatives have central and peripheral impacts. They suppress the spontaneous electrical activity of neurons and block the synaptic transmission of neurotransmitters such as catecholamines and glutamate. Adenosine also affects the behavior, for example by inducing slow wave sleep phase. Getting to the body, adenosine and its derivatives reduce locomotor activity, which can be restored with small doses of caffeine and theophylline. Finally, adenosine has vasodilatory properties, inhibits renin release and platelet aggregation in vitro. Caffeine blocks this action $[5,6,16,17]$.

Caffeine stimulates human central nervous system, enhances cardiac activity, accelerates the pulse, causes expansion of blood vessels (mainly vessels of skeletal muscles, brain, heart, kidneys), enhances urination, reduces platelet aggregation (however, in some situations, opposite effects are possible). This is due to the fact that caffeine blocks the enzyme phosphodiesterase, which destroys cAMP, leading to its accumulation in cells. cAMP is a secondary mediator through which the effects of various physiologically active substances, primarily adrenaline, are realized. Thus, the accumulation of cAMP leads to adrenaline-like effects [16].

The purpose of the article is to draw attention to caffeine as a means of oncological and radiological pharmacology within the framework of drugs' reprofiling [8].

Oncology. Depending on the dose, caffeine has a radiomodifying and antitumor effect $[10,15]$.

In the study [2], caffeine sodium benzoate was used as a modulator of the action of cytostatics, which inhibits the repair of tumor DNA in patients with osteosarcoma. Preoperative polychemotherapy was carried out according to the scheme of 2-4 courses with an interval of 3 weeks for $3.2 \pm 0.8$ months.

Treatment began with intra-arterial injection of cisplatin at a dose of $60 \mathrm{mg} \mathrm{m} / \mathrm{m}^{2}$ and caffeine $1.5 \mathrm{~g} / \mathrm{m}^{2}$ during the first two days. On days $3-4$, doxorubicin was injected $\mathrm{i} / \mathrm{v}$ at a dose of $35 \mathrm{mg} / \mathrm{m}^{2}$.

Preoperative chemotherapy modulation with caffeine in the study group (cisplatin, doxorubicin) made it possible, with less toxicity of treatment, to achieve the number of organsaving operations and the results of therapeutic pathomorphosis similar to the use of high-dose 
methotrexate with cisplatin and doxorubicin in the comparison group. This effect of caffeine requires further study in adjuvant polychemotherapy regimens.

The combination of cisplatin and caffeine demonstrated synergistic growth inhibition of two strains of cultured sarcoma cells tested and 14 of 18 fresh human sarcoma samples $(77.8$ $\%$ ). This synergistic effect of caffeine was also observed with cyclophosphamide $(44.8 \%)$, mitomycin $\mathrm{C}(44.8 \%)$ and adriamycin $(27.8 \%)$. However, the combination of vincristine or methotrexate with caffeine did not show a synergistic effect. Caffeine therefore enhanced the action of four cytotoxic DNA damaging agents. No antagonistic effects were observed in the series. It is assumed that caffeine may be useful for enhancing the antitumor effect of anticancer drugs, especially agents that damage DNA, and, possibly, can help in overcoming natural drug resistance [14].

Caffeine reduced vinblastine-induced chromosomal aberrations and mitotic index in bone marrow cells. The study demonstrates that caffeine has a protective effect against vinblastineinduced cytogenotoxicity. Further studies of the molecular mechanism are of interest for the development of caffeine as an effective drug in cancer chemotherapy [11].

Radiobiology. An experiment (male mice, whole body irradiation, $6.5 \mathrm{~Gy}$ ) demonstrated the caffeine radioprotective effect $(80 \mathrm{mg} / \mathrm{kg}$ body weight, intraperitoneally 1 hour before irradiation) [7].

Caffeine action increases the sensitivity of tumor cells (e.g., lung carcinoma A549) to ionizing radiation. The caffeine radiosensitizing effects are associated with inhibition of protein kinase activity [12].

The survival rate of 6 -week-old male mice under irradiation at a lethal dose of $7 \mathrm{~Gy}$ after intraperitoneal injection of $0.5 \mathrm{ml}$ of $5 \mathrm{mM}$ caffeine solution in $0.9 \% \mathrm{NaCl}(45 \mathrm{mg} / \mathrm{kg}$ of animal weight) before and after $\mathrm{X}$-ray radiation was studied. The animals were irradiated with the therapeutic X-ray unit (RUT-15, RF) at a dose rate of 1 Gy per minute [1]. The average lifespan of the irradiated mice was 8 days, and the maximum living out time was 15 days. With the caffeine injection 15 minutes before X-ray irradiation, a small radiosensitizing effect was observed, the average life span was 7 days, and the maximum living out time was 12 days. The caffeine injection 15 min after X-ray irradiation significantly increased the survival rate of the mice. About $45 \%$ of the animals remained alive for 30 days.

Caffeine reduces the risk of developing skin cancer and melanoma, colorectal cancer [16].

The modulation of radiosensitivity by using caffeine in two human sarcoma cell lines both with a p53 mutation (US8-93 and LMS6-93) was examined [3]. In both cell lines a strong irradiation-induced $\mathrm{G} 2 / \mathrm{M}$ arrest was coupled with a low rate of apoptosis. Incubation with caffeine resulted in a low percentage of $S$ and $\mathrm{G} 2 / \mathrm{M}$ cells, associated with an accumulation in $\mathrm{G} 1$. With a higher caffeine concentration a lower clonogenic survival with IC50at $2 \mathrm{mM}$ was detected. In both cell lines incubation with caffeine completely prevents the irradiationinduced $\mathrm{G} 2 / \mathrm{M}$ arrest. This was connected to radiosensitization, but without direct correlation to an induction of apoptosis. The effect of radio-sensitization rose with higher irradiation doses. However, in comparison with LMS6-93, it was stronger in cell line US8-93. A higher radiosensitization in US8-93 correlated with the prevention of strong irradiation-induced $\mathrm{G} 2 / \mathrm{M}$ response and higher initial DNA damage. Results of Western hybridization reveal a p53independent mechanism of radiosensitization caused by caffeine. 82 women with cervical cancer and 53 with endometrial cancer received primary or adjuvant radiation therapy. Patients were asked about their consumption of caffeinated beverages and the average daily caffeine intake during radiation therapy was estimated. Evaluable patients ( 42 cervix, 31 endometrium) were stratified by the amount of caffeine consumed to correlate with the incidence of radiation toxicity. Acute radiation toxicity has not been associated with caffeine consumption at cervical or endometrial cancer. Non-statistically significant trend towards a decrease in overall late radiation toxicity with an increase in caffeine intake for patients with cervical cancer was observed. Subgroups' analysis demonstrated that this trend was due to a decrease in the incidence of severe late radiation injuries in patients with cervical cancer who consumed higher levels of caffeine during radiation therapy ( $p$ 
$=0.02)$. This relationship was not observed for late toxicity in patients with endometrial cancer due to the low incidence of severe late postexposure trauma for this disease [13].

Conflict of interest information. The author declares no conflict of interest related to the publication of this article

\section{Literature}

1. Асадуллина Н. Р. Радиозащитные свойства ряда пуриновых соединений: автореф. дис. ... канд. биол. наук; спец. : 03.01.01 / Нелли Рустамовна Асадуллина; [Моск. гос. ун-т им. М.В. Ломоносова]. - М., 2012. - 24 с.

2. Чёрный В. С. Применение кофеина в комбинированном лечении больных остеосаркомой / В. С. Чёрный, А. А. Бурьянов, Т. А. Тарасова, В. В. Проценко // Літопис травматології та ортопедії. - 2011. № 1-2. - С. 102-105.

3. Bache M. Loss of G2/M arrest correlate with radiosensitization in two human sarcoma cell lines with mutant p53 / M. Bache, S. Pigorsch, J. Dunst // Int. J. Cancer. - 2001. - Vol. 96. - P. 110-117.

4. Bode A. M. The enigmatic effects of caffeine in cell cycle and cancer/ A. M. Bode, Z. Dong // Cancer Lett. - 2007. - Vol. 8. - P. 26-39. https://doi.org/10.1016/j.canlet.2006.03.032. Epub 2006 May 18. PMID: 16709440; PMCID: PMC2824565.

5. Eldon M. B. The acute oral toxicity of caffeine/ // Toxicology and Applied Pharmacology. - Vol. 1, N3, - 1959. - P. 250-257. https:// doi.org/10.1016/0041-008X(59)90109-7.

6. Evans J. Caffeine/ J. Evans, J. R.Richards, Battisti A. S. // StatPearls [Internet]. Treasure Island (FL): StatPearls Publishing; 2020 Jan. Access from: https://www.ncbi.nlm.nih.gov/ books/NBK519490.

7. Kim J. K. Evaluation of caffeine as a radioprotector in whole-body irradiated male mice / J. K. Kim, J. H. Kim, Y. D. Yoon // In Vivo. - 2003. - Vol. 17(2). - P. 197-200. PMID: 12792986.

8. Kolotilov N. N. Repurposing of Drugs: Radiological Aspect / N. N. Kolotilov, A. Alekseyenko, I. V. Andrushchenko, S. Anton // Radiation Diagnostics, Radiation Therapy. - 2019. -
N 3. - P. 70-73. https://doi.org/10.37336/27070700-2019-3-7.

9. Liu H. Caffeine induces sustained apoptosis of human gastric cancer cells by activating the caspase-9/caspase-3 signalling pathway / H. Liu, Y. Zhou, L. Tang // Mol. Med. Rep. 2017. - Vol. 16(3). - P. 2445-2454. https://doi. org/10.3892/mmr.2017.6894. Epub 2017 Jun 30. PMID: 28677810 ; PMCID: PMC5547974.

10.Geriyol P. Protecting effect of caffeine against vinblastine (an anticancer drug) induced genotoxicity in mice / P. Geriyol, H. B. Basavanneppa, B. L. Dhananjaya // Drug and Chemical Toxicology. - 2015. - Vol. 38(2). - P. 188-195, https://doi.org/10.3109/01480545.201 4.928720

11. Inhibition of ATM and ATR Kinase Activities by the Radiosensitizing Agent, Caffeine /J. N. Sarkaria, E. C. Busby [et. al] // Cancer Res. - 1999. - Vol. 59(17). - P. 4375-4382.

12. Osarieme E. D. The Anticancer Activity Of Caffeine - A Review / E. D. Osarieme, D. T. Modupe, O. P. Oluchukwu // Archives of Clinical and Biomedical Research. - 2019. - Vol. 3. - P. 326-342.

13. Stelzer K. J. Caffeine consumption is associated with decreased severe late toxicity after radiation to the pelvis / K. J. Stelzer, W. J. Koh, H. Kurtz // Int J Radiat. Oncol. Biol. Phys. - 1994. - Vol. 30. - P. 411-417. https:// doi.org/10.1016 / 0360-3016 (94) 90022-1

14. Tomita K. Caffeine enhancement of the effect of anticancer agents on human sarcoma cells / K. Tomita, H. Tsuchiya // Jpn J Cancer Res. - 1989. - Vol. 80(1). - P. 83-88. https:// doi.org/10.1111/j.1349-7006.1989.tb02249.x. PMID: 2496063; PMCID: PMC5917686.

15. Vartanyan L. P. Caffeine derivatives perspective method of the search for anticancer and radiomodifying drugs in combined therapy for malignant brain tumors / L. P. Vartanyan, M. B. Kolesova // Psychopharmacol. Biol. Narcol. - 2005. - Vol. 5, N 4. - P. 1093-1095.

16. Visconti M. J. Therapeutic use of caffeine in dermatology: A literature review / M. J. Visconti // J. Dermatol. Dermatol. Surg. - 2020. Vol. 24, N18-24. https://doi.org/10.4103/jdds. jdds 5219.

17. Willson C. The clinical toxicology of caffeine: A review and case study / C. Willson // Toxicol. Rep. - 2018. - Vol.5. - P. 1140-1152. https://doi.org/10.1016/j.toxrep.2018.11.002. 


\section{DRUGS OF RADIOLOGICAL PHARMACOLOGY. REPROFILING: CAFFEINE}

\author{
N.N. Kolotilov
}

Caffeine $\left(\mathrm{C}_{8} \mathrm{H}_{10} \mathrm{~N}_{4} \mathrm{O}_{2}\right)$ is a purine alkaloid, colorless or white bitter crystals. It is a psychostimulant found in plants such as coffee, tea, cocoa, Paraguayan holly (mate), guarana, cola and others. The plant-based alkaloids related to caffeine are theobromine and theophylline. The fatal acute oral dose of caffeine for humans is estimated at $10-14 \mathrm{~g}(150-200 \mathrm{mg} / \mathrm{kg}$ body weight). As part of the reprofiling of drugs, caffeine is a means of oncological and radiological pharmacology.

Caffeine reduces the risk of skin cancer and melanoma, colorectal cancer developing. Depending on the dose, caffeine has a radioprotective effect, increases the sensitivity of tumor cells to ionizing radiation (the radiosensitizing effects of caffeine are associated with inhibition of the activity of protein kinases), enhances the antitumor effect of chemotherapy drugs, especially agents that damage DNA (possibly, it can help in overcoming natural drug resistance), has protective action against cytogenotoxicity caused by vinblastine.

\section{ЛІКАРСЬКІ ЗАСОБИ РАДІОЛОГІЧНОГО ФАРМАКОЛОГІЇ: ПЕРЕПРОФІЛЮВАННЯ: КОФЕЇН}

\section{М.М. Колотілов}

Кофеїн $\left(\mathrm{C}_{8} \mathrm{H}_{10} \mathrm{~N}_{4} \mathrm{O}_{2}\right)$ - алкалоїд пуринового ряду. $Є$ самим часто приймається нейроактивности препаратом в світі, міститься в рослинах, таких, як кава, чай, какао, мате, гуарана, кола та інших. Родинними кофеїну алкалоїдами рослинного походження є теобромін і теофілін. Смертельна гостра пероральна доза кофеїну для людини оцінюється в 10-14 г (150-200 мг/кг маси тіла).

В рамках перепрофілювання лікарських засобів кофеїн - засіб онкологічної і радіологічної фармакології. Кофеїн зменшує ризики розвитку раку та меланоми шкіри, колоректального раку. Залежно від дози кофеїн має радіопротекторну дію, підвищує чутливість пухлинних клітин до іонізуючого випромінювання (радіосенсібілізірующего ефекти кофеїну пов'язані з пригніченням активності протеїнкіназ), підсилює протипухлинну дії хіміопрепаратів, особливо агентів, що ушкоджують ДНК (можливо, може допомогти в подоланні природної лікарської стійкості), надає захисну дію проти цітогенотоксічності, викликаної вінбластином.

\section{ЛЕКАРСТВЕННЫЕ СРЕДСТВА РАДИОЛОГИЧЕСКОЙ ФАРМАКОЛОГИИ: ПЕРЕПРОФИЛИРОВАНИЕ: КОФЕИН}

\section{Н.Н. Колотилов}

Кофеи́н $\left(\mathrm{C}_{8} \mathrm{H}_{10} \mathrm{~N}_{4} \mathrm{O}_{2}\right)$ - алкалоид пуринового ряда. Является самым часто принимаемым нейроактивным препаратом в мире, содержится в растениях, таких, как кофе, чай, какао, мате, гуарана, кола и других. Родственными кофеину алкалоидами растительного происхождения являются теобромин и теофиллин. Смертельная острая пероральная доза кофеина для человека оценивается в 1014 г (150-200 мг/кг массы тела).

В рамках перепрофилирования лекарственных средств кофеин - средство онкологической и радиологической фармакологии. Кофеин уменьшает риски развития рака и меланомы кожи, колоректального рака. В зависимости от дозы кофеин обладает радиопротекторным действием, повышает чувствительность опухолевых клеток к ионизирующему излучению (радиосенсибилизирующие эффекты кофеина связаны с ингибированием активности протеинкиназ), усиливает противоопухолевое действия химиопрепаратов, особенно агентов, повреждающих ДНК (возможно, может помочь в преодолении естественной лекарственной устойчивости), оказывает защитное действие против цитогенотоксичности, вызванной винбластином. 